\title{
Yanrui Wu, China's Economic Growth : A Miracle with
} Chinese Characteristics

London and New York, RoutledgeCurzon, 2004, 143 p.

\section{Cécile Batisse}

\section{OpenEdition}

\section{Journals}

Édition électronique

URL : http://journals.openedition.org/chinaperspectives/642

DOI : $10.4000 /$ chinaperspectives.642

ISSN : 1996-4617

\section{Éditeur}

Centre d'étude français sur la Chine contemporaine

Édition imprimée

Date de publication : 1 juin 2006

ISSN : 2070-3449

\section{Référence électronique}

Cécile Batisse, "Yanrui Wu, China's Economic Growth : A Miracle with Chinese Characteristics », China

Perspectives [En ligne], 65 | may - june 2006, mis en ligne le 21 décembre 2006, consulté le 21

septembre 2020. URL : http://journals.openedition.org/chinaperspectives/642 ; DOI : https://doi.org/

10.4000/chinaperspectives.642

Ce document a été généré automatiquement le 21 septembre 2020.

(C) All rights reserved 


\title{
Yanrui Wu, China's Economic Growth : A Miracle with Chinese Characteristics
}

\author{
London and New York, RoutledgeCurzon, 2004, 143 p.
}

\author{
Cécile Batisse
}

\section{NOTE DE L'ÉDITEUR}

Translated from the French original by Philip Liddell

1 Yanrui Wu's book provides the reader with a valuable toolbox of statistical information and reflection for assessing Chinese growth over the decades following the creation of the People's Republic of China. While the subject is not new, Dr Wu's contribution is offered as a relatively rigorous synthesis of earlier work alongside some original research. With the help of a specially designed database the reader can test various hypotheses using statistical and econometric methods.

2 The writer begins with a brief review of the context in which his book appears and of the development of the Chinese economy since 1949, focusing mainly on the period since the reforms. Thereafter, the book is set out in three parts. The first studies Chinese growth and its determining factors on a countrywide scale. The second assesses the development and the impact of growth at the provincial level. In the third and final part, Dr Wu examines two key sectors in the context of the reforms: telecommunications and energy.

3 The analysis of growth and the economic reforms is fairly conventional. The main contribution is provided by Chapter Two : having described the connection between formation of capital and economic growth in the literature, $\mathrm{Wu}$ offers a measurement of the capital stock in China at the national and regional level over a long period. This data is available in an appendix to the book. Thus, the writer emphasises the basic role played by the accumulation of capital in China's growth.

4 Taking as its standpoint the classical texts on growth theory, Chapter Three goes on to examine the traditional economic and political sources of Chinese growth. It highlights 
the economic adjustment within the main areas of China (western, central and coastal), while noting the very weak convergence between them.

For $\mathrm{Dr} \mathrm{Wu}$, while Chinese growth is closely connected to the addition of production capacity, it derives also from productivity in manufacturing, which he seeks to emphasise in Chapter Four (thus making his own contribution to the debate over the sustainability of Chinese growth in the long term).

6 The analysis of growth at the provincial level addresses two main issues. Firstly, Chapter Five develops the questions of growing provincial disparities and of convergence. The section putting into perspective the various books on the subject is particularly instructive. The following chapter examines the impact of the economic integration of Hong Kong, Taiwan and the provinces of Guangdong and Fujian.

7 Dr Wu rounds off his book with two sector-based studies. Telecommunications and energy have experienced rapid growth generated by the significant increase in demand. The development of the energy sector is closely connected to the tensions created by economic growth: the subject reflects the contemporary debate over the future of Chinese growth and the country's place on the world scale.

We must applaud the thoroughness of this study, while remarking in addition that it is enjoyable to read and clearly argued. Yet, the first question one has to ask is whether the statistics are reliable. This is widely questioned today, a fact that is not mentioned. Furthermore, one of the author's primary intentions is to show that the contribution made by growth to the accumulation of physical capital is very significant. However, he offers no reflection on the fact that this accumulation is not necessarily beneficial when it increases the industrial over-capacity of state enterprises that are unproductive. Nor does he comment on the need for it to play a diminishing role as the productivity of capital increases. In recent years, Chinese growth has been marked by periods of overheating caused by excessive investment. Raw materials and building materials have been going up in price. Overheating is most apparent in the energy and transport sectors and over-capacity is appearing in several sectors, such as cars and textiles. The book is of interest in that it tackles numerous aspects and issues relating to growth : convergence, productivity, regional disparities and economic integration. But it occasionally sins in developing these themes too rapidly. They would have merited more meticulous critical analysis and discussion. 